\title{
Expression of resistin in testis and epididymis of bulls
}

\author{
H. Mohammadi, B. Shokrollahi
}

Department of Animal Science, Faculty of Agriculture, Sanandaj branch, Islamic Azad University, Sanandaj, Iran

*Corresponding author E-mail: Borhansh@gmail.com, Borhansh@iausdj.ac.ir; Tel: +98 $8733288661-3$

Journal of Livestock Science (ISSN online 2277-6214) 10: 86-90

Received on 10/7/2019; Accepted on 30/9/2019

doi. 10.33259/JLivestSci.2019.86-90

\begin{abstract}
The resistin is an insulin-antagonizing factor that also plays a regulatory role in inflammation, immunity, food intake, and gonadal function. Although adipose tissue is the primary source of resistin, it is also expressed in other tissues, including the testis. This study was aimed to investigate the immunohistochemical (IHC) localization of resistin in testicular tissues of Holstein bulls. Mouse monoclonal antibody anti-resistin as primary antibody and rabbit anti-mouse IgG Horseradish Peroxidase (HRP) as secondary antibody were used. Samples of testis were collected from four bulls aged of 1.5 to 2 years old, and preserved in $10 \%$ formalin for posterior inclusion in paraffin. Histological sections with 5 micron in thickness were prepared for IHC. Immunoreactions were assessed for spermatogenic cells, Leydig cells, Sertoli cells and epididymis. Our results showed that the resistin is expressed in the testis. Immunoreactions were observed in Sertoli cells, Leydig cells, spermatogonia cells and cytoplasm of ciliated cells of the epididymis. But, the intensity of staining in Leydig cells and epididymis was very weak in comparison with other cells. Probably, resistin had autocrine effect in testis, therefore it could be involved in spermatogenesis and sperm motility.
\end{abstract}

Key words: Resistin; Sertoli; Leydig; epididymis; bull 


\section{Introduction}

The adipose tissue is an important endocrine organ that secretes several protein hormones, including leptin, adiponectin, and resistin. These hormones generally influence energy metabolism, closely associated with type 2 diabetes mellitus and obesity. Insulin resistance and atherosclerosis have been extensively studied, making a strong relation between obesity and increased morbidity. Recently, a direct relationship between obesity and lower steroids production and infertility has been discussed (Jean et al., 2012).

Resistin as a cysteine-rich poly peptide and signaling molecule, is made during adipogenesis and secreted by adult adipocytes (Steppan et al., 2001b). Resistin is mainly involved in the modulation of insulin sensitivity and adipocyte differentiation. Plasma resistin is associated with insulin resistance in lean and obese human subjects (Silha et al., 2003). However, although serum resistin levels were found to be elevated in rodent models for obesity, and diet-induced obesity (Steppan et al., 2001b), studies have shown a decrease in resistin production in certain obese rodent models (Rajala et al., 2004). Nonetheless, with its increased production related to the severity of obesity, resistin plays a major role in linking adipose tissue accumulation to type 2 diabetes (Steppan et al., 2001b). Oppositely, deficiency in resistin production decreases hepatic gluconeogenesis and serum glucose levels (Banerjee et al., 2004). Resistin stimulates the proliferation and migration of satellite liver cells while inhibiting their apoptosis via interleukin 6 (IL6) and the monocyte chemotactic protein-1 mechanism (Dong et al., 2013). Other metabolic and endocrine effects of this hormone remain unknown (Banerjee et al., 2004). The expression of the resistin gene has been demonstrated in rat testis throughout postnatal development, with maximum mRNA levels in adults (Nogueiras et al., 2004). At this age, resistin is detected in interstitial Leydig cells and Sertoli cells of the seminiferous tubules, and its production is regulated by pituitary gonadotropins (Nogueiras et al., 2004). Thus, resistin, among the other adipose derived hormones, might play a role in steroidogenic genes regulation in Leydig cells. A research has shown that resistin might influence steroidogenic genes expression and Leydig cells function (Jean et al., 2012). It has been reported that resistin has no effect on progesterone production, despite an increase in nuclear translocation of STAT factors and unexpected 3',5'-cyclic adenosine monophosphate (cAMP) dependent increase in synthesis of steroidogenic acute regulatory protein and cholesterol side-chain cleavage enzyme (Jean et al., 2012). In addition, exposure to normal doses of resistin could have beneficial effects on Leydig cell function, as it contributes to increase the viability and proliferation of these cells (Jean et al., 2012). Resistin expression has not been reported in cattle testicles until now, therefore the aim of this research was to localization of resistin in testicular tissue of bull by immunohistochemistry.

\section{Materials and Methods}

Samples of testicular tissues were obtained from four Holstein bulls, aged between 1.5 and 2 years old. The testes were excised immediately after slaughter, fixed in $10 \%$ formalin, and paraffin-embedded. In this study, 5 serial sections for each sample were used with $\mu \mathrm{m}$ sections, mounted on slides coated with a suitable tissue adhesive; section were deparaffinized and rehydrated (Bayezidi-Azar \& Shokrollahi, 2016; Sadegh-Vaziri et al., 2017; Mansouri \& Shokrollahi, 2017). A heat-treatment was performed for antigen retrieval. Finally, indirect IHC technique was performed after heat treatment for antigen retrieval using citrate buffer (10 mM, $\mathrm{pH}=6$ ) for break of protein cross-links (Bayezidi-Azar \& Shokrollahi, 2016; Sadegh-Vaziri et al., 2017; Mansouri \& Shokrollahi, 2017). Peroxide block (5 min) was used to neutralize endogenous peroxides. Protein block (5 min) was used to block non-specific binding sites. For resistin detection a mouse monoclonal antibody anti resistin (Cat No: ab136877, abcam) as primary antibody and Rabbit Anti-Mouse IgG Horseradish Peroxidase (HRP) (Cat No: ab6728, abcam) as secondary antibody was used. The sections were incubated overnight with the primary antibody diluted $1 / 500$ in PBS, in a moist chamber at $4{ }^{\circ} \mathrm{C}$. Thereafter, slides were incubated with post primary block $(30 \mathrm{~min})$, followed by incubation $(20 \mathrm{~min})$ with a secondary antibody diluted $1 / 300$ in PBS and developed peroxides activity with DAB (diaminobenzidine) working solution (15 min). The sections were finally counterstained with hematoxylin and dried and mounted with cytology glue. In the control, normal rabbit serum at the same dilution as the primary antibody alone was applied instead of primary antibody. Then the prepared slides were coded and examined with an optical microscope. Finally, the positive reaction was identified by intensely dark brown staining in cells.

\section{Results}

In current study, the resistin was localized in Leydig cells, Sertoli cells, spermatogonium cells, spermatids and epididymis of Holstein bulls. According to the hematoxylin eosin staining of the bull testis in Fig 1, different cells can be observed. As shown in Fig 2B and Fig 2C, color reactions were observed in Leydig cells, Sertoli cells, spermatogonium cells, spermatids, Moreover, resistin was expressed in epididymis tubules of bull testis (Fig 3B and Fig 3C). Negative control in Fig 2A and Fig3A showed that there were no reaction of immunoprooxidase when the rabbit serum was used instead of mouse monoclonal antibody as primary antibody. 
The results approved that the reaction is completely specific for resistin antibody therefore the expression of resistin in bull testis was confirmed.

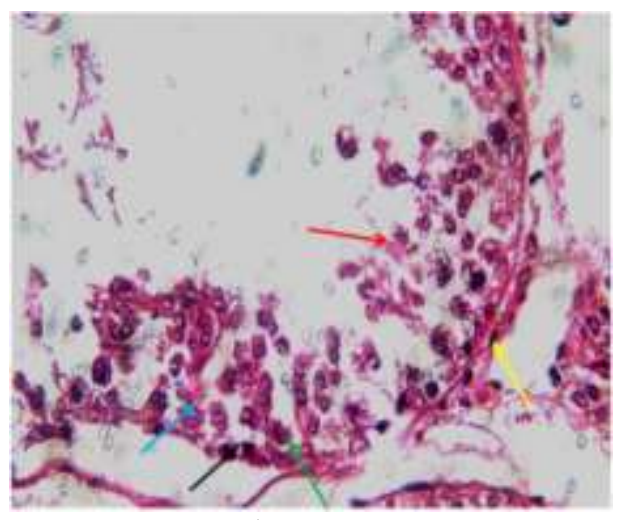

A

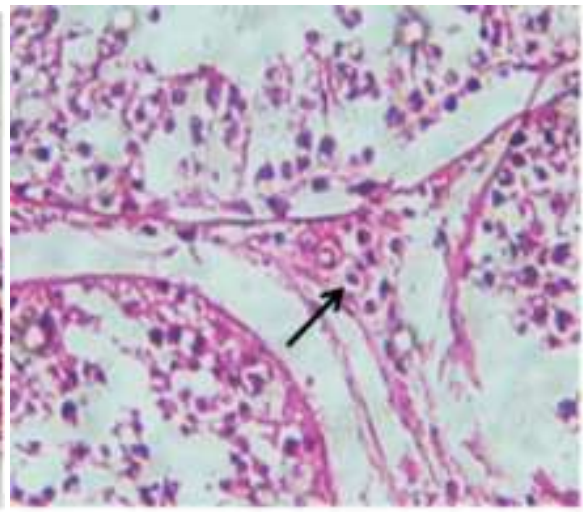

B

Fig 1: General structure of the testis of the bull (Hematoxylin eosin staining). A) Objective magnification $\times 100$, myoid, sertoli, spermatogonia, early spermatocyte and spermatid cells are marked with yellow, blue, black, green and red arrows, respectively. B) Objective magnification $\times 400$, leydig cells are marked with black arrow

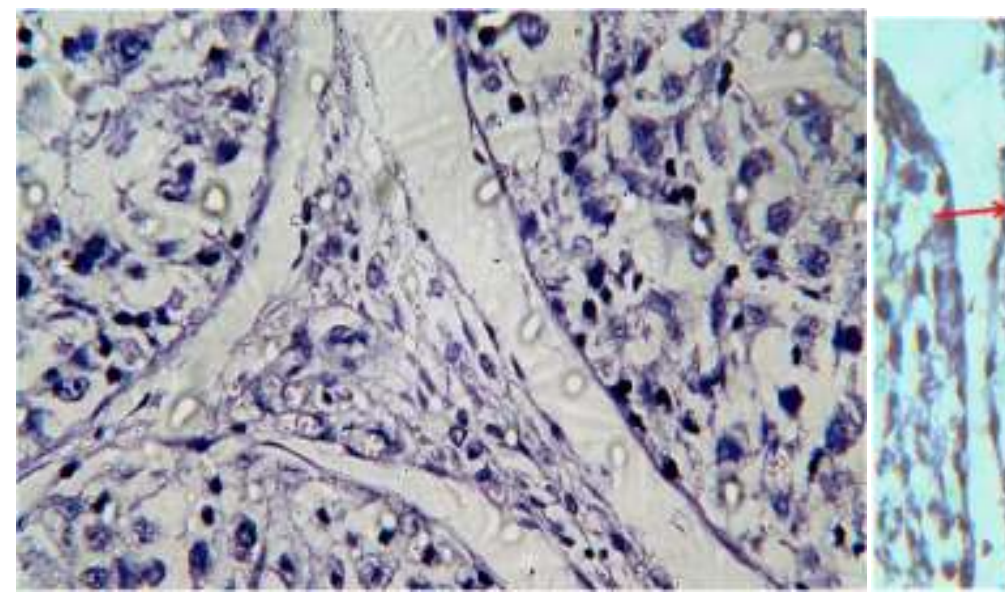

A



B

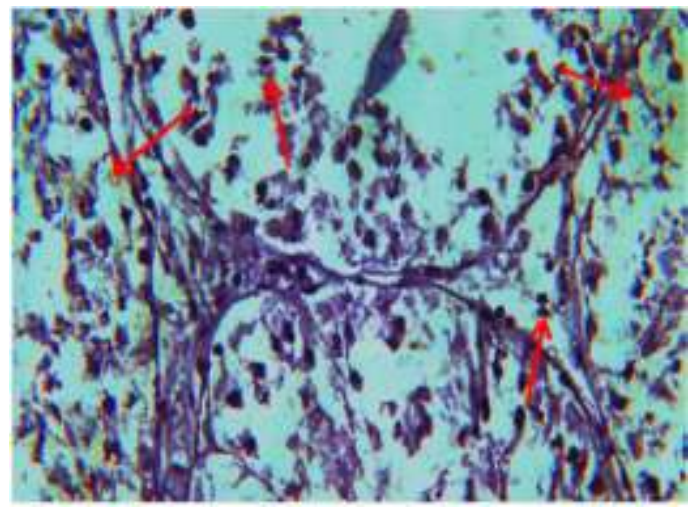

$\mathrm{C}$

Fig 2 (Objective magnification $\times 400)$ : A) Negative control: Sample incubated with rabbit serum instead of primary antibody, the lack of dark brown color in the Leydig cells indicates a negative reaction to the immunoprooxidase. B) Specimen incubated with anti-resistin monoclonal antibody prepared from mice. Dark brown color in sertoli and spermatogonia cells represents a positive reaction of immunoprooxidase. C) An inoculated sample with a specific anti-resistin monoclonal antibody prepared from mice. Dark brown color in the Leydig cells (very poorly colored), sertoli cells, and spermatogonia indicate a positive reaction of the immunoprooxidase.

\section{Discussion}

Regarding the findings of the current study, resistin antigen in Leydig cells, spermatogonial cells, Sertoli cell and ciliated cells of epididymis was detected, therefore, the immunoprooxidase reaction was observed in the cytoplasm of Leydig cells, spermatogonial cells, Sertoli cells, and cytoplasm of epididymis cells. 


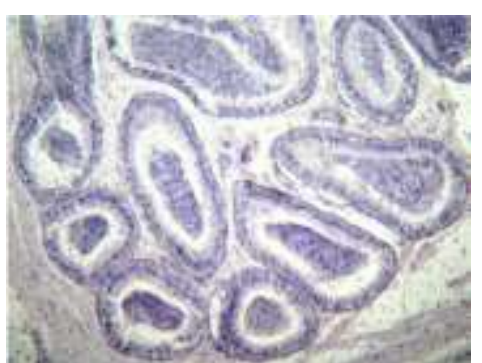

A

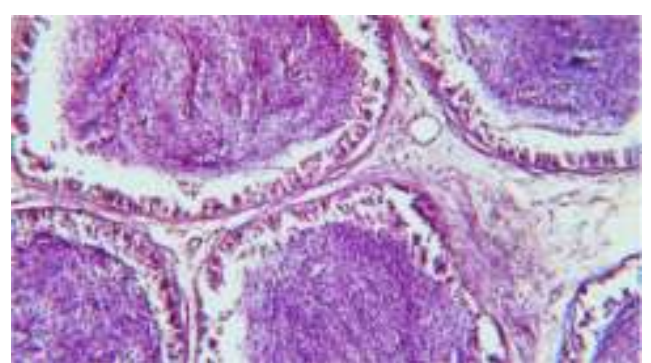

B

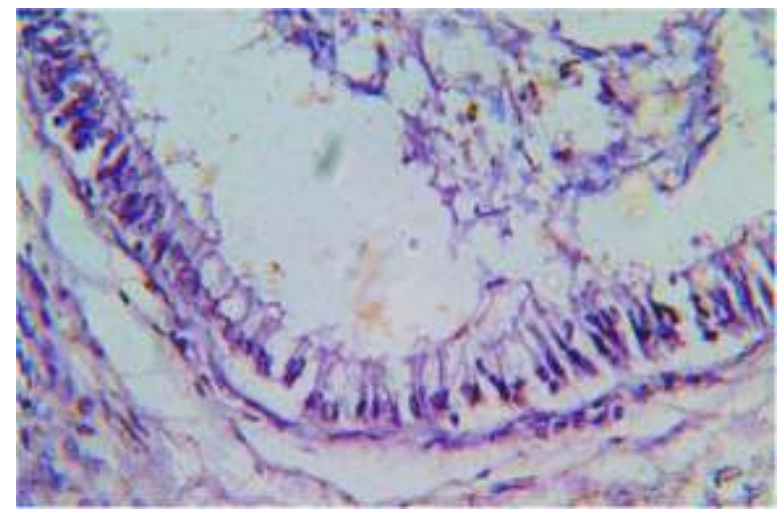

$\mathrm{C}$

Fig 3: A) Negative control (Objective magnification $\times 40$ ): Sample incubated with rabbit serum instead of primary antibody. The lack of dark brown color in the cytoplasm of the epididymis cells represents a negative reaction of the immunoprooxidase. B) (Objective magnification $\times 100$ ) and C) (Objective magnification $\times 400$ ): cross section of cattle epididymal tissue which incubated with anti-resistin monoclonal antibody prepared from mouse. Dark brownish color in the cytoplasm of epididymis ciliated cells represents a positive reaction of the immunoprooxidase.

Color intensity was weak in all specimens and the severity of the reaction in the Leydig cells was very poor compared to other tissues. It seems that each cell can participate in the synthesis or expression of resistin in different manner. Probably, resistin in these cells has a direct role in regulation of testicular secretions through steroidogenesis. In this research, resistin in the ruminant reproductive system of males is reported for the first time, although its presence has been reported in the testicles of rats (Nogueiras et al., 2004). Resistin has emerged as a novel adipocytokine with potential implications in the modulation of insulin sensitivity and adipocyte differentiation (Kim et al., 2001; Steppan et al., 2001a). However, a substantial argument on the actual role of resistin in obesity-associated insulin resistance has done (Ukkola, 2002), and in addition, further physiological effects of resistin remain largely unknown. Expression of resistin has been reported in tissues and cell types other than the adipose, including endothelial and vascular smooth cells, peripheral mononuclear cells and macrophages in humans (Savage et al., 2001; Patel et al., 2003), as well as hypothalamus, pituitary, gastrointestinal tract and adrenal gland in rodents (Morash et al., 2002; Nogueiras et al., 2003). Thus, endocrine and nonendocrine actions of resistin other than control of glucose tolerance are possible (Nogueiras et al., 2004). Testicular expression of resistin was investigated by molecular and immunological procedures in rats and the results demonstrated that the resistin gene is expressed in rat testis throughout postnatal development. The major expression of resistin within the testis occurs in Leydig cells (Nogueiras et al., 2004). In a study, the regulation of testicular resistin expression by gonadotropins was surveyed (Fauser et al., 2002). The results showed that both LH and FSH participate in the tuning of resistin expression in rat testis, with partially different roles. In a gonadotropin deficient background, a significant decrease in resistin mRNA levels was noted, whereas treatment with hCG (as superagonist of LH), but not FSH, was able to restore resistin mRNA expression. In contrast, in a normal gonadotropin background, FSH stimulation evoked a persistent elevation of resistin levels up to 24 hours (Nogueiras et al., 2004). The ability of FSH to acutely stimulate resistin mRNA was confirmed using a culture system of isolated seminiferous tubule fragments at different stages of the seminiferous epithelial cycle. This approach also demonstrated that expression of the resistin gene in seminiferous tubules is stage-specific. The results strongly suggest that expression of testicular resistin is subjected to precise regulation, involving stimulatory effects of pituitary gonadotropins. Based on similarities with other factors involved in the control of energy status and/or adipose function, such as leptin and ghrelin, it is tempting to hypothesize that resistin may operate as a novel endocrine integrator linking energy homeostasis and reproduction (Nogueiras et al., 2004). In testis, resistin might enhance steroids production by Leydig cells via stimulation of cells viability and proliferation. Since Leydig cells produce resistin in low concentrations, they may control their own proliferation in an autocrine or paracrine manner (Roumaud \& Martin, 2015). Indeed, exposure to small concentrations of resistin $(10 \mathrm{ng} / \mathrm{mL})$, corresponding to a normal physiological condition, contributes to increased proliferation of 
MA-10 Leydig cells (Jean et al., 2012). In addition, Sertoli cells may also contribute to Leydig cells proliferation by secreting resistin (Nogueiras et al., 2004). Therefore, resistin is among other adipose derived hormones that might play a role in steroidogenic genes regulation in Leydig cells.

In this study, we reported the presence of resistin antigen in spermatogonium, Sertoli, Leydig and epididymis cytoplasm cells for the first time in cattle. Resistin produced in such cells might have effect on the steroidogenesis of these cells locally and can play a role in spermatogenesis and sperm motility.

\section{References}

1Banerjee, R.R., Rangwala, S.M., Shapiro, J.S., Rich, A.S., Rhoades, B., Qi, Y., Wang, J., Rajala, M.W., Pocai, A., Scherer, P.E., Steppan, C.M., Ahima, R.S., Obici, S., Rossetti, L. and Lazar, M.A., 2004. Regulation of fasted blood glucose by resistin. Science, 303, 1195-8.

2 Bayezidi-Azar, A. and Shokrollahi, B., 2016. Immunohistochemical Localization of Ghrelin in Testicular Tissues of Holstein Bulls. Iranian Journal of Applied Animal Science, 6, 551-5.

3 Dong, Z.-X., Su, L., Brymora, J., Bird, C., Xie, Q ,.George, J. and Wang, J.-H., 2013. Resistin mediates the hepatic stellate cell phenotype. World Journal of Gastroenterology: WJG, 19, 4475.

4 Fauser, B.C., Rutherford, A., Bouchard, P., Strauss, J.F., Hsueh, A.J., Van Steirteghem, A. and Simpson, J., 2002. Reproductive medicine: molecular, cellular and genetic fundamentals. Taylor \& Francis.

5 Jean, S., Landry, D., Daigle, M. and Martin, L.J., 2012. Influence of the adipose derived hormone resistin on signal transducer and activator of transcription factors ,steroidogenesis and proliferation of Leydig cells. Asian Pacific Journal of Reproduction, 1, 1-6.

6 Kim, K.-H., Lee, K., Moon, Y.S. and Sul, H.S., 2001. A cysteine-rich adipose tissue-specific secretory factor inhibits adipocyte differentiation. Journal of Biological Chemistry, 276, 11252-6.

7 Mansori, K. and Shokrollahi, B., 2017. Immunohistochemical localization of ghrelin in goat testicular tissue. Veterinary Journal (Pajouhesh-Va-Sazandegi), 30 (2115), 185-193.

8 Morash, B.A., Willkinson, D., Ur, E. and Wilkinson, M., 2002. Resistin expression and regulation in mouse pituitary. FEBS Letters, 526, 26-30.

9 Nogueiras, R., Barreiro, M.L., Caminos, J.E., Gaytan, F., Suominen, J.S., Navarro, V.M., Casanueva, F.F., Aguilar, E., Toppari, J., Dieguez, C. and Tena-Sempere, M., 2004. Novel expression of resistin in rat testis: functional role and regulation by nutritional status and hormonal factors. Journal of Cell Sciences, 117, 3247-57.

10 Nogueiras, R., Gallego, R., Gualillo, O., Caminos, J.E., Garcia-Caballero, T., Casanueva, F.F. and Dieguez, C., 2003. Resistin is expressed in different rat tissues and is regulated in a tissue- and gender-specific manner. FEBS Letters, $548,21-7$.

11 Patel, L., Buckels, A.C., Kinghorn, I.J., Murdock, P.R., Holbrook, J.D., Plumpton, C., Macphee, C.H. and Smith, S.A., 2003. Resistin is expressed in human macrophages and directly regulated by PPAR gamma activators. Biochemistry Biophysic Research Communication, 300, 472-6.

12 Rajala, M.W., Qi, Y., Patel, H.R., Takahashi, N., Banerjee, R., Pajvani, U.B., Sinha, M.K., Gingerich, R.L., Scherer, P.E. and Ahima, R.S., 2004. Regulation of resistin expression and circulating levels in obesity, diabetes, and fasting. Diabetes, 53, 1671-9.

13 Roumaud, P. and Martin, L.J., 2015. Roles of leptin, adiponectin and resistin in the transcriptional regulation of steroidogenic genes contributing to decreased Leydig cells function in obesity. Hormone Molecular Biology and Clinical Investigation, 24, 25-45.

14 Sadegh-Vaziri, S., Shokrollahi, B., and Mohammadi, S., 2017. Ghrelin localization in testicular and epididymis tissues of ram. Veterinary Journal (Pajouhesh-Va-Sazandegi), 30 (1114), 75-81

15 Savage, D.B., Sewter, C.P., Klenk, E.S ,.Segal, D.G., Vidal-Puig, A., Considine, R.V. and O'Rahilly, S., 2001. Resistin / Fizz3 expression in relation to obesity and peroxisome proliferator-activated receptor-gamma action in humans. Diabetes, 50, 2199-202.

16 Silha, J.V., Krsek, M., Skrha, J.V., Sucharda, P., Nyomba, B.L. and Murphy, L.J., 2003. Plasma resistin, adiponectin and leptin levels in lean and obese subjects: correlations with insulin resistance. Eurupean Journal of Endocrinology, 149, 331-5.

17 Steppan, C.M., Bailey, S.T., Bhat, S., Brown, E.J., Banerjee, R.R., Wright, C.M., Patel, H.R., Ahima, R.S. and Lazar, M.A., 2001a. The hormone resistin links obesity to diabetes. Nature, 409, 307-12.

18 Steppan, C.M., Brown, E.J., Wright, C.M., Bhat, S., Banerjee, R.R., Dai, C.Y., Enders, G.H., Silberg, D.G., Wen, X. and Wu, G.D., 2001b. A family of tissue-specific resistin-like molecules. Proceedings of the National Academy of Sciences, 98, 502-6.

19 Ukkola, O., 2002. Resistin - a mediator of obesity-associated insulin resistance or an innocent bystander? Eurupean Journal of Endocrinology, 147, 571-4. 